\title{
Species richness and phytogeography of the Bryophyte flora of the Guianas, with special reference to the lowland forest ${ }^{\star}$
}

\author{
S.R. Gradstein, D. Montfoort and J.H.C. Cornelissen \\ Institute of Systematic Botany, Heidelberglaan 2, Utrecht, The Netherlands \\ *Studies on the flora of the Guianas 46. Dedicated to Jeanne Florschütz-de Waard on the occasion of her 65th \\ birthday.
}

\begin{abstract}
The Guianas (French Guiana, Suriname, Guyana) are probably one of the last areas of the world covered largely by virgin lowland rain forest. Species diversity of epiphytic bryophytes was investigated in dry evergreen forest and mixed forest using mountaineering techniques to ascend into the canopy. The results indicate that the lowland rain forest is richer in species than previously believed due to neglect of the canopy flora, which may hold more than $50 \%$ of the local species. The mixed forest holds the richest flora and on one single forest tree up to 67 bryophyte species were found ( 50 on average); 28 trees yielded 154 species. A species/area curve indicates that epiphytic bryophyte species are usually commonly distributed in the forest and a few trees may yield much of the local flora.

A recent checklist of the Guianas includes over 600 species of bryophytes: 375 Hepaticae and 234 Musci. As the region lacks in altitude (except on Mt. Roraima) the general character of the bryophyte flora of the Guianas is typically lowland neotropical. Over $80 \%$ of the species are rather widespread in tropical America (Amazonian species included), and the remaining are Guayana Highlands, northern Amazonian or Caribbean elements. Endemism is very low: $2.5 \%$.
\end{abstract}

\section{Introduction}

The Guianas are situated between $1^{\circ}-9$ North and $51^{\circ}-62^{\circ}$ West, and comprise the countries French Guiana (an overseas French Department), Suriname (formerly Dutch Guiana) and Guyana (formerly British Guiana). The latter two are now independent countries. The total area of the Guianas is about 470,000 square kilometers.

The Guianas are one of the last areas of the world covered largely by virgin rain forest. A reason for the presence of vast areas of untouched rain forest is the very thin population of the region, which totals ca. 1.3 million people. Rainfall varies between about 2000-4000 $\mathrm{mm}$ annually (values may be higher in the mountains) and there are one or two dry seasons which last 1-3 month each (Lindeman and Mori 1989).

Most of the population is concentrated in the coastal region, where the forest gives way to swamps, savannas and cultivated land. The interior of the Guianas is rather hilly, with numerous small mountain ranges not exceeding $1000 \mathrm{~m}$. in altitude. The highest mountains of the Guianas are the sandstone table mountains or tepuis of the Guayana Highlands, which extend 


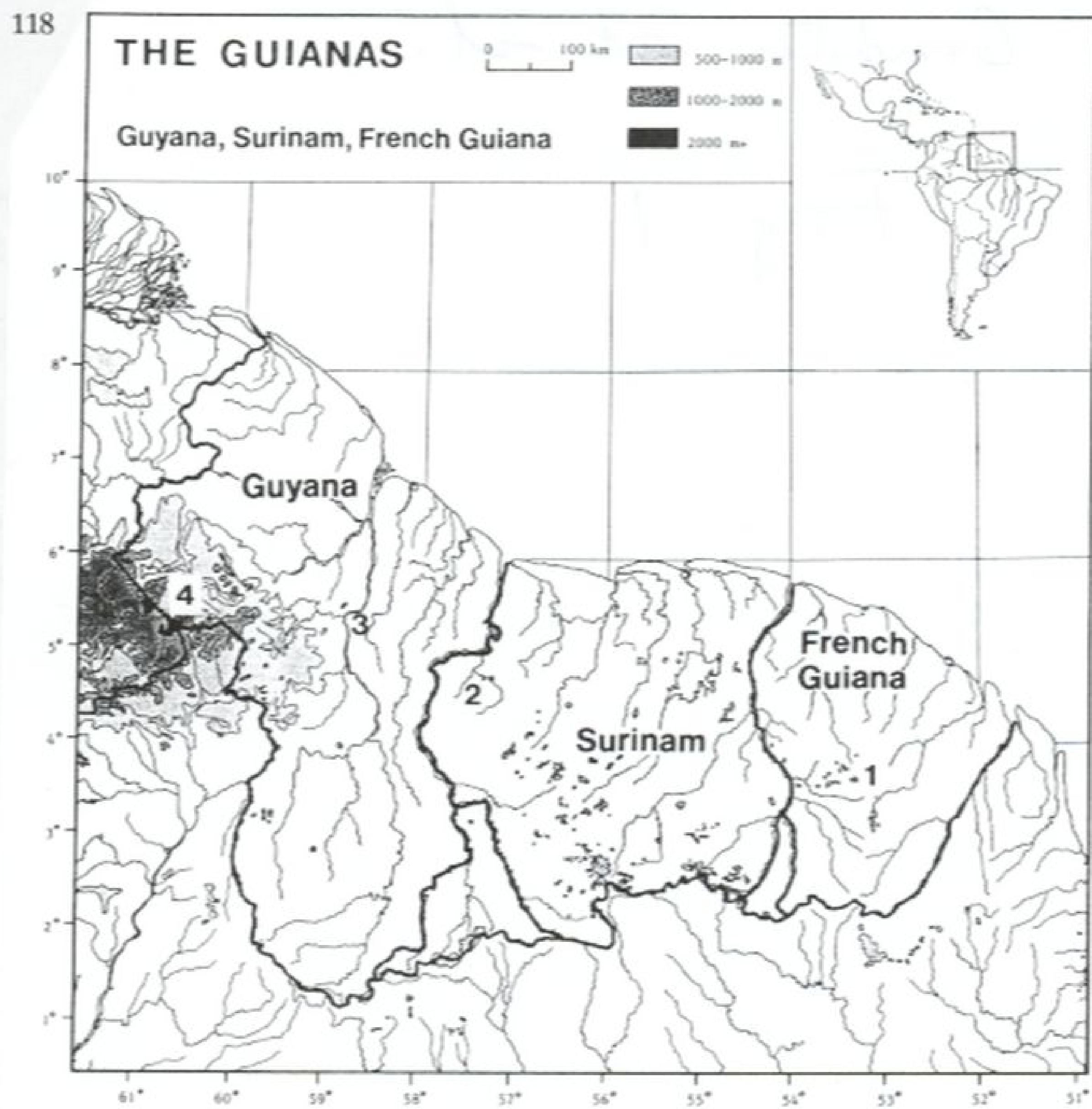

Fig. 1. Map of the Guianas, showing the main areas where bryophyte inventories of the rainforest were carried out recently. 1. Saül, French Guiana (Montfoort and Ek pers. comm.) 2. Kabalebo, western Suriname (Florschütz-de Waard and Bekker 1987). 3. Mabura Hill, Guyana (Cornelissen and Ter Steege 1989; Biesmeijer and Bleij pers. comm.) 4. Upper Mazaruni District (incl. Mount Roraima), Guyana (Gradstein and Florschǘtz-de Waard 1989).

in the east. In Venezuela the tepuis reach up to $3000 \mathrm{~m}$. but in the Guianas they are much lower and usually about $1000-1200 \mathrm{~m}$. high. The highest peak of the Guianas is Mount Roraima $(2750 \mathrm{~m}$.) at the border of Venezuela, Guyana and Brazil. This is the only mountain in the Guianas which harbours a well-developed montane flora.

The bryophyte flora of the Guianas became known in the 19th century by the important collections of F.R.M. Leprieur from French Guiana (Montagne 1835, 1851) and H.A.H. Kegel from Suriname (Müller 1848, Lindenberg and Gottsche 1851), which hold many types. Later, Richards (e.g. 1952, 1954) did his pioneering work on tropical rainforest ecology and the bryophyte communities of lowland rain forest at Moraballi Creek in Guyana. Florschütz (1964) and Florschütz-de Waard (1986) produced an important treatment of the mosses of the Guianas in the 'Flora of Suriname'. The liverworts of the Guianas remained poorly known, however.

In recent years the senior author, together with his research associates, carried out investigations on the bryophyte flora of the Guianas in the framework of the 'Flora of the Guianas' project (Florschūtz-de Waard and Bekker 
with his research associates, carried out investigations on the bryophyte flora of the Guianas in the framework of the 'Flora of the Guianas' project (Florschütz-de Waard and Bekker 1987, Frahm and Gradstein 1987, Inoue \& Gradstein 1988, Grolle and Gradstein 1988, Cornelissen and Ter Steege 1989, Gradstein and Hekking 1989, Gradstein \& Florschützde Waard 1989). Main goals of the program were to inventory selected areas (Fig. 1) with the purpose of obtaining more insight in the bryophyte richness and diversity of the various habitats within the Guianas, in particular the rain forest, and to produce a checklist for the region as a basis for future Flora treatments and phytogeographic studies. The present paper briefly reviews some of the results.

\section{Species Richness of the Lowland Rain Forest}

The Guianan rain forest has been described by Richards (1952) and De Granville (1988). Richards (1934, 1954, 1984), moreover, was the first to study the species richness of the rain forest bryophytes. At Moraballi Creek, Guyana, in an area of a few square kilometers entirely covered with lowland rain forest, he found 48 species of mosses in four months of collecting. About 48 species of liverworts were identified, but as about half of the liverwort collection was lost before identification, the number of liverworts is uncertain and is estimated by the author to be as much as 100. The author concluded that the lowland rain forest is rather poor in species and that there are more liverwort species than mosses.

Florschütz-de Waard and Bekker (1987) compared species richness and diversity in the understory of three different lowland rainforest types (dry-evergreen or savanna forest, marsh or inundated forest, mixed or mesophytic forest) in West Suriname, in an area of about 200 square kilometers. Although epiphyllous liverworts were not taken into account, the authors could confirm that liverworts are more numerous than mosses in the rain forest. Species richness proved highest in periodically flooded marsh forest: 41 mosses and 70 liverworts. Fewer species were found in the mixed forest (34 mosses, 47 liverworts) and the dry evergreen forest (26 mosses, 44 liverworts). The authors suggested that the higher air humidity, betterillumination and somewhat lower average temperature in the understory of the marsh forest, as compared to the other forest types, were responsible for the higher species richness in the former. They also found significant floristic differences among the three forest types, especially among the mosses. These results are in general agreement with data from other areas (see Richards 1984).

Although Florschütz-de Waard and Bekker inventoried a much larger area than Richards, they found fewer species of bryophytes. Presumably this is due to the fact that their study was restricted to the understory of the forest. The bryophyte flora of the canopy of the rain forest is very poorly known. Until recently, information about its composition has been obtained mainly from felled trees and fallen branches. Richards (1984) found that the tree crowns have fewer species than the understory and only about half of the species in the former are also found in the latter. Presumably many canopy species may occur outside the forest in relatively exposed locations at low levels, for instance in scrub, orchards, on roadside trees and on rock. The available data are fragmentary, however, and do not allow for firm conclusions.

In order to obtain more detailed information on the bryophyte flora of the rainforest canopy, inventories were recently carried out in the different rainforest types of the Guianas by graduate students from the University of Utrecht. Whole standing trees were sampled by means of a modified mountaineering technique(Ter Steege and 


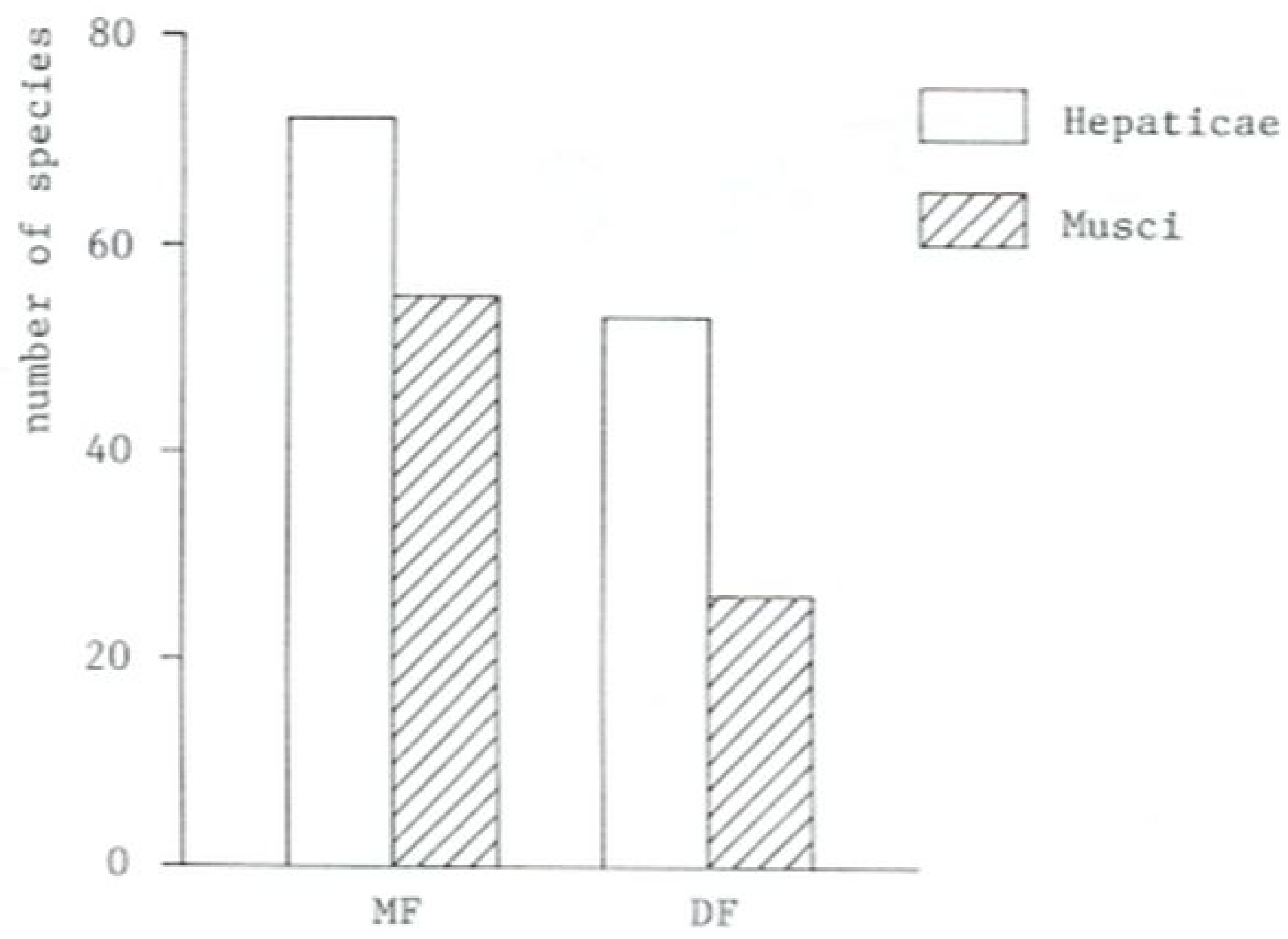

Fig. 2. Species richness of bryophytes in the mixed forest (MF) of Saül, French Guiana and the dry evergreen forest (DF) of Mabura Hill, Guyana.

forest. Presumably the higher humidity in the mixed forest, the greater richness in tree species and the larger diversity in microhabitats of the latter account for the larger number of species found in the mixed forest. While most of the sampled trees in the mixed forest are different species, those sampled in the dry evergreen belong to only two species of 'wallaba' (Eperua falcata, E. grandiflora).

As expected, our figures on species richness of the different forest types are much higher than those given by Florschütz-de Waard and Bekker (1987) for the understory of the forest. It appears that in the dry evergreen forest more than half of the species are restricted to the tree crowns and the upper portions of the trunks (Table 1). In the mixed forest this percentage is somewhat lower and more species from the tree crowns are also found lower down on the trunks. On one single tree in the mixed forest of French Guiana (Saūl) up to 67 bryophyte species were found; the minimum number per tree was 29 , the average number 50 . In comparison, these figures were 54,12 and 32 respectively for lichens and 64, 25 and 46 respectively for vascular epiphytes (Ek \& Montfoort, pers. comm.) Nine species of trees carried more than 90 species of cryptogamic epiphytes (bryophytes and lichens) on single host individuals and the highest number of cryptogamic species recorded on one single tree (Protium sp.) was 106. The number of epiphytic species found in the mixed forest of French Guiana are the highest thus far recorded for lowland rainforest.

Previous authors have suggested that bryophyte species richness in the tropical lowland rain forest is much lower than in tropical montane rain forest and may also be lower than in temperate forests (Richards 1984, Schuster 1988, Gradstein \& Pocs 1989). None of these studies took full account of the canopy flora, however. Our data from the Guianan rain forest indicate that species richness of epiphytic bryophytes in tropical lowland rainforest is usually higher 


\begin{tabular}{|c|c|c|c|}
\hline & Mosses & Liverworts & Total \\
\hline $\begin{array}{l}\text { exclusively above } 10 \mathrm{~m} \text {. } \\
\text { exclusively below } 10 \mathrm{~m} . \\
\text { both above and below } 10 \mathrm{~m} \text {. }\end{array}$ & $\begin{aligned} 16 & (55 \%) \\
2 & (7 z) \\
11 & (38 z)\end{aligned}$ & $\begin{aligned} 22 & (47 \pi) \\
6 & (13 \%) \\
19 & (40 \%)\end{aligned}$ & $\begin{aligned} 38 & (50 z) \\
8 & (11 \%) \\
30 & (39 z)\end{aligned}$ \\
\hline
\end{tabular}

Table 1. Occurrence of epiphytic bryophyte species above and below $10 \mathrm{~m}$. height on eleven trees (Eperua falcata, E. grandiflora) in the dry evergreen forest ("wallaba forest") of Mabura Hill, Guyana. Numbers of species are given.

than in temperate forests; it is lower than in tropical montane rainforests, although less than previously assumed. Barkman (1959) found on average 20-30 species of cryptogamic epiphytes (bryophytes and lichens) per tree in The Netherlands, with a maximum of 45 . Individual trees in a montane rainforest of Colombia at $2500 \mathrm{~m}$., however, carry 70 species of bryophytes on average and on four trees 112 bryophyte species were found (Wolf pers. comm.); three fourth of them are liverworts.

Vertical distribution patterns on the tree differ greatly among individual epiphytic species, and usually a distinction can be made between 'specialists', which have a narrow vertical amplitude and 'generalists', which show little height preference (Cornelissen and Ter Steege 1989). A difference in vertical distribution was also observed between corticolous and epiphyllous species in the mixed forest (Fig. 3). Whereas the number of corticolous species per tree increases towards the outer canopy, epiphyl- lous species decrease in number. Epiphylls require more shade and higher humidity than many other epiphytes and are thus largely confined to the understory and the shaded lower part of the canopy (Richards 1984).

A species/area curve for epiphytic bryophytes of the mixed forest of French Guiana indicates that most bryophyte species are common in the forest and a few trees may yield much of the local bryophyte flora (Fig. 4). An inventory of twenty eight trees, belonging to twenty two different species, yielded 154 species of bryophytes (Montfoort \& Ek pers. comm.) About $75 \%$ of the species were collected on five trees only and each additional tree sampled yielded only few (1-3) new species. Species area curves for tree base and tree crown separately are rather similar, but with $75 \%$ limits reached at slightly larger numbers of trees (ca. 10-13 trees). Apparently the minimum area for epiphytic bryophytes in this forest is very small, as opposed to tree species (Mori 1987). The results 

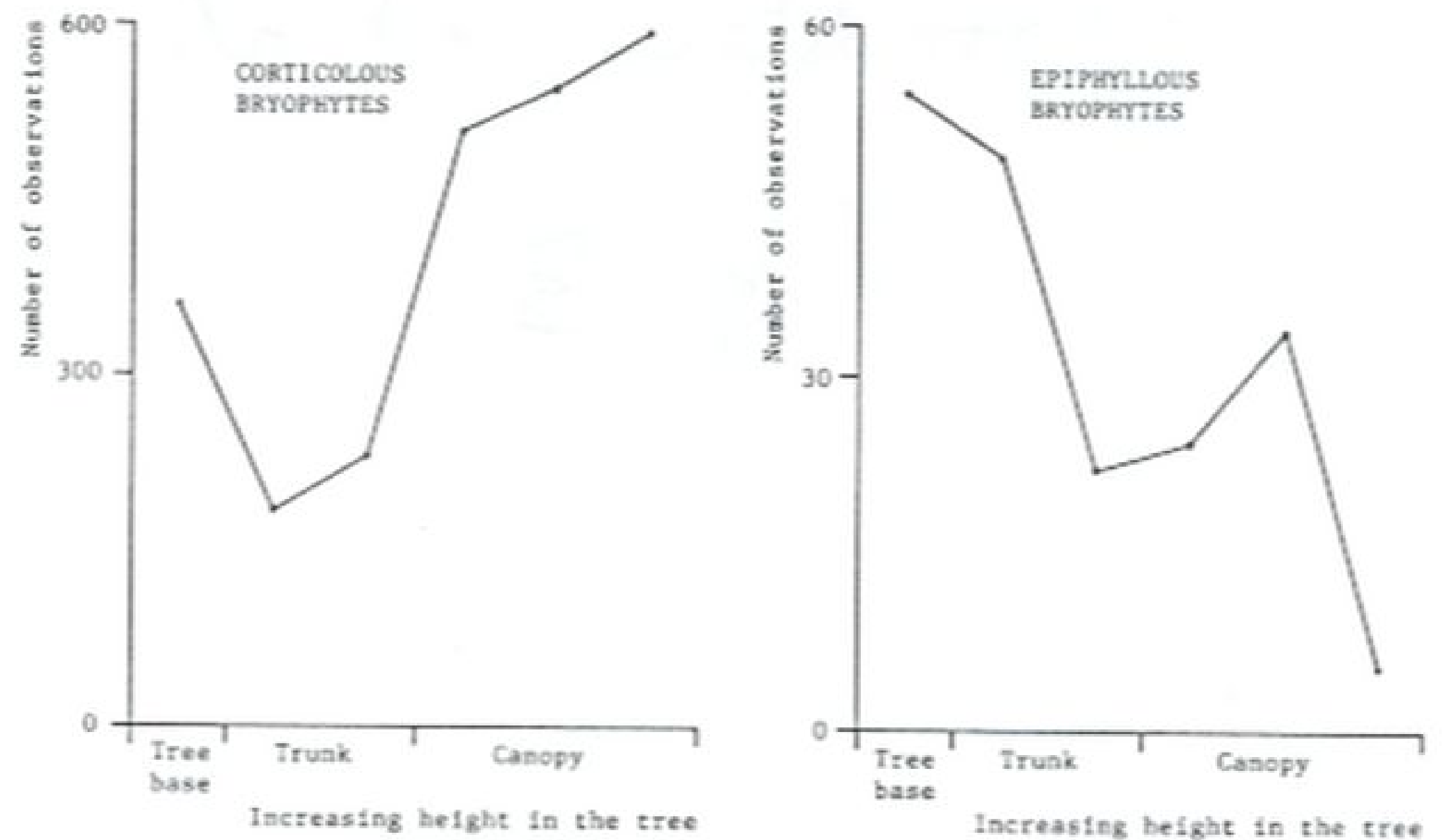

Fig. 3. Vertical distribution of corticolous and epiphyllous bryophytes on trees in the mixed forest of Saül, French Guiana.

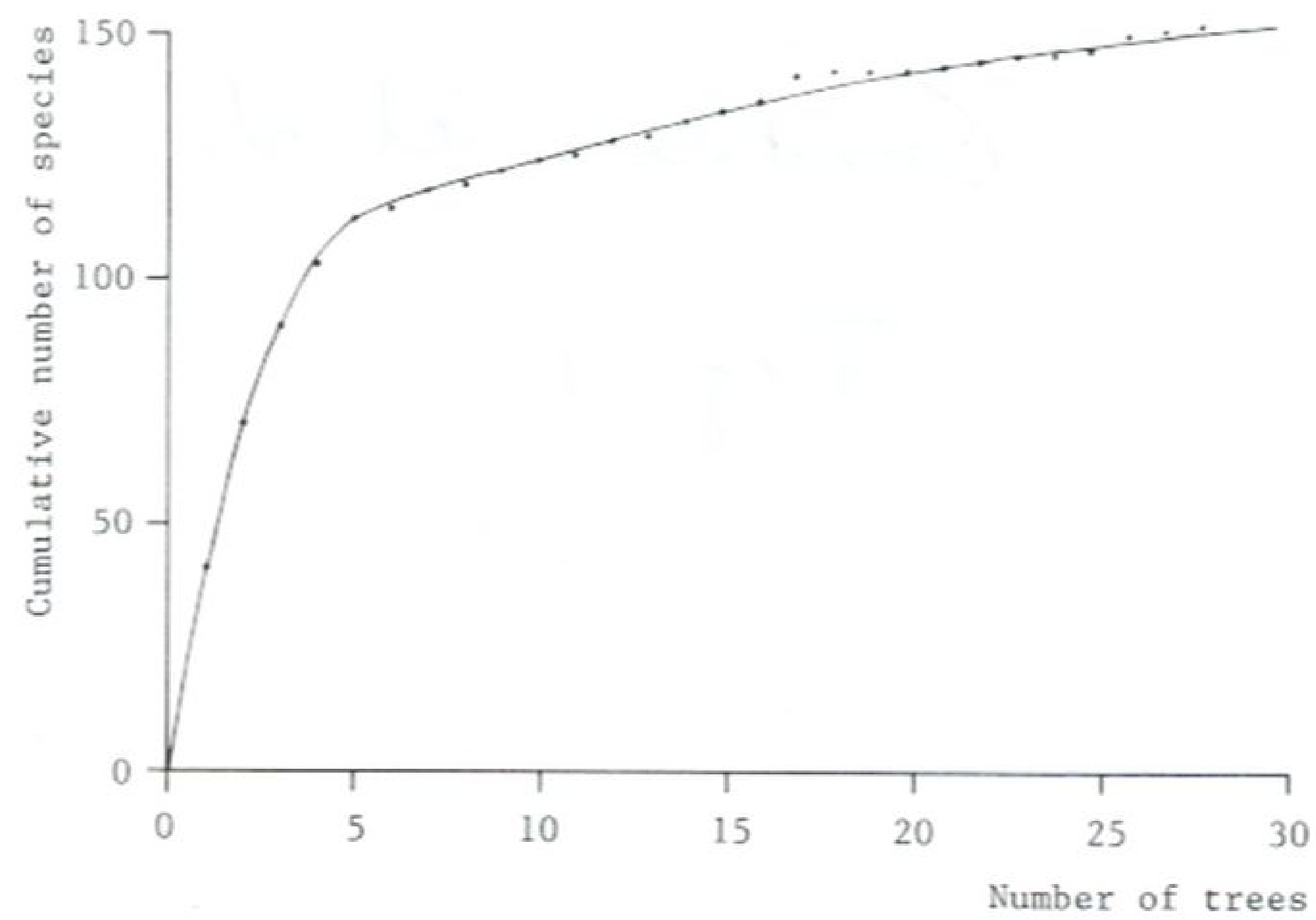

Fig. 4. Species/area curve of epiphytic bryophytes in the mixed forest of Saül, French Guiana. Area is expressed by number of trees sampled. 
species per tree increases towards the outer canopy, epiphyllous species decrease in number. Epiphylls require more shade and higher humidity than many other epiphytes and are thus largely confined to the understory and the shaded lower part of the canopy (Richards 1984).

A species/area curve for epiphytic bryophytes of the mixed forest of French Guiana indicates that most bryophyte species are common in the forest and a few trees may yield much of the local bryophyte flora (Fig. 4). An inventory of twenty eight trees, belonging to twenty two different species, yielded 154 species of bryophytes (Montfoort \& Ek pers. comm.) About $75 \%$ of the species were collected on five trees only and each additional tree sampled yielded only few (1-3) new species. Species area curves for tree base and tree crown separately are rather similar, but with $75 \%$ limits reached at slightly larger numbers of trees (ca. 10-13 trees). Apparently the minimum area for epiphytic bryophytes in this forest is very small, as opposed to tree species (Mori 1987). The results support the notion that the bryoflora of the lowland rainforest may berather uniform (e.g. Schuster 1988), although the richness in species is certainly higher than previously believed.

\section{Phytogeography}

The recent checklists of the bryophytes of the Guianas include 234 species of mosses (Florschütz-de Waard pers. comm.) and 375 species of liverworts (Gradstein and Hekking 1989). Some further liverworts not included in the checklist are reported by Gradstein and Florschütz-de Waard (1989). The actual bryophyte flora of the region may be estimated at about 250 species of mosses and 400 liverworts, taking into account revisions of old names and new discoveries.

The majority of the bryophyte species seem to be rather widespread in Tropical America. Guianan species with more limited distributions fall in one of the following five categories:

1. Guayana Highlands element (17 spp.). This category includes (sub)montane species which are largely restricted to the tepuis of the Guayana Highlands. In the Guianas most of these species are only known from the North slope of Mount Roraima (see Gradstein and Florschützde Waard 1989). Many of them are restricted to the eastern portion of the Guayana Highlands, which seems to be a speciation center for bryophytes: the 'Gran Sabana' element (Robinson 1986). Species that belong to the latter element are marked "(GS)".

Mosses: Brachymenium sipapoense, Dicranoloma brittonae (also Panama), Leucomium steerei (GS), Trichostomum duidense.

Liverworts: Adelanthus squarrosus (GS), Calypogeia venezuelana, Echinocolea sp. nov. (GS), Haesselia acuminata (GS), $H$. roraimensis (GS), Micropterygium grandistipulum (GS), M.tenax, $M$. tumidulum (GS), Mytilopsis albifrons, Pleurozia heterophylla (GS) Radula gradsteinii (GS), Trabacellula tumidula (GS), Vanaea plagiochiloides (GS).

2. Northern Amazonian element (20 spp.). This category includes species restricted to the lowland rain forests and savannas at the northern outskirts of the Amazon basin and the Upper Orinoco. Their range extends maximally from eastern Colombia to the state of Para, Brasil. Some of them go up the lower slopes of the Guayana Highlands, up to ca. $1000 \mathrm{~m}$. Lowland taxa endemic to the Guianas (marked 'E') are included in this category, as well as species from the rich upper Rio Negro flora (Spruce 1884-85). Mosses: Calymperes mitrafugax (E), Fissidens geyskesii (E), Hydropogon fontinaloides, Micromitrium telephorothecium (also northeastern Brazil), Sphagnumnegrense, Syrrhopodon 
helicophyllus, S. hornschuchii.

Liverworts: Arachniopsis pecten, Drepanolejeunea integribracteata $(\mathrm{E})$, Frullania sp. nov., Haplolejeunea cremersii (E), Marsupidium gradsteinii, Plagiochila gymnocalyx, Pteropsiella serrulata, Radula guyanensis $(\mathrm{E}), R$. mazarunensis (E), Schusterolejeunea inundata, Stenorrhipis grollei (E), Stictolejeunea balfourii var. bekkeri(E), Zoopsismacella.

3. Amazonian element. This category includes species occurring throughout the Amazon basin and in the Guianas, but not elsewhere. A full list of the Amazonian species cannot yet be given, however, and needs further work. Examples are the mosses Calymperes platyloma, $C$. rubiginosum, Octoblepharum cocuiense and Syrrhopodon simmondsii and the liverworts Archilejeunea juliformis, Archilejeunea crispistipula, Calypogeia miquelii, Lepidolejeunea ornata, Neurolejeunea seminervis, Pycnolejeunea callosa and Verdoornianthus griffinii. In view of the great floristic similarity of the Guianan and Amazonian rainforests (Prance 1989), the Amazonian element could be expected to be a significant component of the Guianan bryophyte flora. However, we estimate that the total percentage will not exceed 5-10\%, as many bryophyte species of these lowland forests occur elsewhere in the neotropics as well.

4. Caribbean element (31 spp.). These are oceanic species which are largely restricted to the West Indian islands but in addition occur in adjacent (coastal) continental regions. Some are quite rare in the Guianas and are known there by only one or two collections (e.g. Calymperes guildingii, Plagiochiladussiana, Cystolejeunea lineata), others are rather common in the Guianas such as Groutiella obtusa and Campylopus cubensis. A few are restricted to the coastal plain of the Guianas (Frullanoides corticalis), but the majority of the Caribbean species occur in the interior, in particular on the table mountains. Pócs (1988) recognized Caribbean-Guayana links in his phytogeographical analysis of the Cuban bryophyte flora.

Mosses: Brachymenium wrightii, Calymperes guildingii, $C$. smithii, $C$. venezuelanum, Campylopus cubensis, Eucamptodontopsis pilifera, Groutiella obtusa, Lepidopilidium portoricense, Leskeodon cubensis, Macromitrium leprieurii, M. trinitensis, Octoblepharum erectifolium.

Liverworts: Alobiella husnotii, Bazzania longa, Calypogeia cellulosa, Colura clavigera, C. greig-smithii, $C$. rhynchophora, Cystolejeunea lineata, Frullanoides corticalis, Drepanolejeunea pinnatiloba, Micropterygium carinatum, Leptoscyphus ovatus, Lopholejeunea quelchii, Metzgeria innovans, Microlejeunea crenulifolia, M. epiphylla Nowellia evansii, Plagiochila dussiana, Riccardia schwaneckei, Symphyogyna marginata.

5. Disjunctelement (8spp.). This category includes Guianan species with disjunct ranges, which are difficult to explain. Examples are the Andean Campylopus luteus, Omphalanthus paramicola and Rhacocarpus purpurascens, which in the Guayana Highlands have been recorded only from Mt. Roraima. Presumably they occur on other tepuis further westwards as well. Campylopus surinamensis and $C$. trachyblepharon represent a 'savanna element' which is disjunct in southeastern Brazil, the Guianas and southeastern North America (Frahm \& Gradstein 1987). Finally, at least three species are GuianasCentral America disjuncts: Renauldia paradoxica, which is only known from western Panama and Mt. Roraima (Gradstein and Florschütz-de Waard 1989); Leptolejeunea mexicana, known from Mexico, the Guianas and S.E. Brazil (Bischler 1969); and Leptolejeunea foraminulosa from Mexico and the Guianas (Bischler 1969). The GuianasCentral America disjunction is also known 
from forest tree species (Prance 1989) and may be relictual, resulting from extinction in parts of a former continuous range due to past climatic changes.

In conclusion, it appears that the bryophyte flora of the Guianas is largely (80-85\%) made up of widespread neotropical or pantropical species. Many of them may have originated in the Amazon basin, but the number of species actually restricted to that area (Amazonian element) may not exceed 5-10\% of the Guianan bryophyte flora. About $5 \%$ of the species are restricted to the Guayana Highlands or to the northern portion of the Amazon basin, and may have originated there. Another $5 \%$ are Caribbean species which presumably colonized the Guianas from the West Indian islands. Two mosses and twelve liverworts are endemic to the Guianas, totalling no more than about $2.5 \%$ of the total flora. The majority of them occur on the North slope of Mount Roraima, which is indeed by far the richest locality for bryophytes in the Guianas (Gradstein \& Florschütz-de Waard 1989). The very low endemism in the bryophyte flora of the Guianas is probably due to the lack of high mountain ranges and the proximity of the region to Amazonia, allowing the species to distribute freely beyond the borders of the territory.

Acknowledgements.We thank William R. Buck and Dana Griffin III for checking some of the moss distributions.

\section{Literature Cited}

Barkman, J.J. 1959. Phytosociology and ecology of cryptogamic epiphytes. Assen.

Bischler, H. 1969. Le genre Leptolejeunea (Spruce) Steph. en Amerique. Nova Hedwigia 17:265-350.

Cornelissen, J.H.C. and ter Steege, H. 1989. Distribution and ecology of epiphytic bryophytes and lichensin dry evergreen forest of Guyana. Journal of Tropical Ecology 5: 131-150.

De Granville, J.J. 1988. Phytogeographical characteristics of the Guianan forests. Taxon 37: 578-594.

Florschütz, P.A. 1964. The mosses of Suriname, Part I. Leiden.
Florschütz-de Waard, J. 1986. The mosses of Suriname, Part II.

Florschütz-de Waard, J. \& Bekker, J. 1987. A comparative study of the bryophyte flora of various forest types in West Suriname. Cryptogamie, Bryologie et Lichénologie 8: 31-45.

Frahm, J.-P. and Gradstein, S.R. 1987. The genera Bryohumbertia and Campylopus (Musci) in the Guianas. Cryptogamie, Bryologie etLichénologie 8:311-319.

Gradstein, S.R. and Florschütz-de Waard, J. 1989. Results of a botanical expedition to Mount Roraima, Guyana. I. Bryophytes. Tropical Bryology 1.

Gradstein, S.R. and Hekking, W.H.A. 1989. A catalogue of the bryophytes of the Guianas. I. Hepaticae and Anthocerotae. Journal of the Hattori Botanical Laboratory 66: 197-230. Gradstein, S.R. and Pócs, T. 1989. Bryophytes. In: H. Lieth and M.J.A. Werger (eds.), Tropical Rain Forest Ecosystems, p. 311- 325. Elsevier, Amsterdam.

Grolle, R. and Gradstein, S.R. 1988. Haesselia, a new genus of Cephaloziaceae (Hepaticae) from Mount Roraima, Guyana. Journal of the Hattori Botanical Laboratory 64: 327 344.

Inoue, H. and Gradstein, S.R. 1988. A remarkable new species of Anastrophyllum (Spruce) Steph. (Hepaticae) from Mt. Roraima, Guyana. Bulletin of the National Science Museum, Tokyo, ser. B, 14: 87-91.

Lindeman, J. and Mori, S. 1989. The Guianas. $\underline{\text { nn: Campbell }}$ D. \& Hammond, H.D. (eds.), Floristic Inventory of Tropical Forests, p. 376-390. New York.

Lindenberg, J.G.B. and Gottsche, C.M. 1851. Plantae Kegelianae. Expositio Hepaticarum Surinamensium. Linnaea 24:625-639.

Montagne, J.P.F.C. 1835. Enumération des Mousses et des Hépaticés récueillies par M. Leprieur dans la Guiane centrale...Annales des Sciences Naturales, Botanique, série 2, 3: (193-)210-219.

Montagne, J.P.F.C. 1851. Cryptogamia guyanensis seu plantarum cellularium in Guyana Gallica annis $1835-1849 \mathrm{aCl}$. Leprieur collectarum enumeratio universalis I. Annales des Sciences Naturales, Botanique, série 3, 16:47-81.

Müller, C.M. 1848. Plantae Kegelianae Surinamenses, Musci frondosi.Linnaea21:181-200.

Pócs, T. 1988. Biogeography of the Cuban bryophyte flora. Taxon 37:615-621.

Prance, G.T. 1989. Tropical American Forests. In: H. Lieth and M.J.A. Werger (eds.), Tropical Rain Forest Ecosystems, p. 99- 132. Elsevier, Amsterdam.

Richards, P.W. 1934. Musci collected by the Oxford Expedition to British Guanain 1929. Kew Bull. Misc. Inf. 8:317-337. Richards, P.W. 1952. The tropical rain forest: an ecological study. Cambridge.

Richards, P.W. 1954. Notes on the bryophyte communities of lowland rain forest with special reference to Moraballi creek, British Guiana. Vegetatio 5-6:319-327.

Richards, P.W. 1984. The ecology of tropical forest bryophytes. In: R.M. Schuster(ed.), New Manual of Bryology Vol.2,p. 1233-1270. The HattoriBotanical Laboratory, Nichinan. Robinson, H. 1986. Notes on the Bryogeography of Venezuela. The Bryologist 89:8-12.

Schuster, R.M. 1988. Ecology, reproductive biology and dispersal of the Hepaticae in the Tropics. Journal of the Hattori Botanical Laboratory 64:237-269.

Spruce, R. 1884-85. Hepaticae amazonicae et andinae. 
